\title{
SELF-ESTEEM REMAJA PEREMPUAN DAN KAITANNYA DENGAN PENGASUHAN PENERIMAAN-PENOLAKAN IBU DAN INTERAKSI SAUDARA KANDUNG
}

\author{
Hotmauli Adina Riska ${ }^{1^{*}}$, Diah Krisnatuti ${ }^{1}$ \\ ${ }^{1}$ Departemen Ilmu Keluarga dan Konsumen, Fakultas Ekologi Manusia, Institut Pertanian Bogor, Bogor 16680, \\ Indonesia
}

*)E-mail : hotmauli.riska@gmail.com

\begin{abstract}
Abstrak
Masa remaja adalah masa perkembangan transisi antara masa kanak-kanak dan masa dewasa yang melibatkan perubahan biologis, kognitif dan sosial. Perubahan tersebut tentunya akan berdampak langsung terhadap penilaian remaja tentang dirinya sendiri. Tujuan penelitian ini adalah untuk menganalisis self-esteem remaja perempuan anak kedua dan kaitannya dengan pengasuhan ibu serta interaksi saudara kandung. Jumlah contoh penelitian ini adalah 60 orang remaja perempuan (30 remaja dengan kakak perempuan dan 30 remaja dengan kakak laki-laki). Penelitian ini merupakan penelitian cross-sectional study dengan teknik pemilihan contoh secara sengaja (purposive). Hasil penelitian ini menunjukkan interaksi saudara kandung pada dimensi kehangatan remaja dengan kakak perempuan lebih tinggi daripada remaja dengan kakak laki-laki. Pengasuhan penerimaan ibu memiliki hubungan positif dengan usia dan lama pendidikan ibu. Sementara itu, pengasuhan penolakan ibu memiliki hubungan positif dengan interaksi saudara kandung pada dimensi kekuatan relatif. Selain itu, pengasuhan agresivitas dan penolakan ibu memiliki hubungan positif dengan interaksi saudara kandung pada dimensi konflik. Pengasuhan agresivitas, pengabaian, dan penolakan ibu memiliki hubungan negatif dengan interaksi saudara kandung pada dimensi persaingan. Hasil uji hubungan antara self-esteem dengan pengasuhan penerimaan-penolakan ibu dan interaksi saudara kandung menunjukkan bahwa hanya pengasuhan penerimaanpenolakan ibu yang secara signifikan berhubungan dengan self-esteem remaja perempuan anak kedua.
\end{abstract}

Kata kunci: interaksi saudara kandung, pengasuhan penerimaan-penolakan, remaja perempuan, self-esteem

\section{SELF-ESTEEM OF GIRLS AND ITS RELATIONSHIP WITH PARENTAL ACCEPTANCE- REJECTION OF MOTHER AND SIBLINGS INTERACTION}

\begin{abstract}
Adolescence is development transitional developmental period between childhood and adulthood which includes biological change, cognitive, and social changes. The changes have a direct impact on their evaluation about themselves the attitudes and behavior of adolescents. The purpose of this research was to analyze the influence of self-esteem of girls who as second children and its correlation with parental acceptance-rejection (PAR) of the mother, and sibling interaction, and self-esteem among second-born adolescent girl. Samples of this research were 60 adolescent girls (30 with an older sister and 30 with an older brother). This was a cross-sectional study with purposive sampling. The result of this study showed that warmth dimension of sibling interaction of girl who has an older sister was higher than the girl who has an older brother. There was the positive correlation between girl's age and mother's education with acceptance dimension of PAR. Meanwhile, rejection dimension of PAR had a positive correlation with the relative power dimension of sibling interaction. Furthermore, hostility and rejection dimension of PAR had a positive correlation with conflict dimension of sibling interaction. Meanwhile, hostility, neglect, and rejection dimension of PAR had a negative correlation with sibling rivalry dimension of sibling interaction. Correlation test found that self-esteem of girls only correlated significantly with the entire dimension of PAR.
\end{abstract}

Keywords: Parental Acceptance-Rejection (PAR), self-esteem, siblings interaction, teenage girls

\section{PENDAHULUAN}

Masa remaja adalah masa perkembangan transisi antara masa kanak-kanak dan masa dewasa yang mencakup perubahan biologis, kognitif, dan sosial. Santrock (2003) menyatakan bahwa masa remaja dimulai pada usia 10 hingga 13 tahun dan berakhir pada usia 18 hingga 22 tahun. Hal tersebut memunculkan istilah remaja awal dan remaja akhir. Sementara itu, menurut Undang-Undang Nomor 4 tahun 1979 tentang Kesejahteraan 
Anak, remaja adalah individu yang belum mencapai 21 tahun dan belum menikah. Jumlah remaja di Indonesia tidaklah sedikit seperti yang ditunjukkan berdasarkan data Badan Pusat Statistik. BPS (2013) menunjukkan remaja pada kelompok umur usia 10 hingga 19 tahun di Indonesia berjumlah 43.743.700 jiwa pada tahun 2010 . Setelah 10 tahun diperkirakan jumlah individu remaja meningkat menjadi 45.674 .800 jiwa. Selanjutnya, pada tahun 2030 proyeksi remaja telah mencapai 47.177.900 jiwa dan ada peluang jika jumlah remaja melebihi dari angka yang telah diprediksi.

Masa remaja menjadi lebih penting dibandingkan periode lainnya karena adanya perubahan fisik dan psikologis yang dialami individu. Perubahan tersebut tentunya akan berdampak langsung terhadap sikap dan perilaku remaja, bahkan dapat berdampak jangka panjang (Hurlock, 1980). Menurut Santrock (2003), untuk melalui periode tersebut, remaja perlu mengevaluasi dirinya yang akan menghasilkan harga diri atau gambaran diri (self-esteem). Namun, tidak semua remaja memiliki gambaran diri positif yang menyeluruh tentang dirinya, bahkan tidak semua remaja mampu memahami dirinya. Untuk sebagian remaja, rendahnya rasa percaya diri hanya menyebabkan rasa tidak nyaman. Namun bagi beberapa remaja, rendahnya rasa percaya diri dapat menyebabkan depresi, bunuh diri, gangguan makan psikologis (anorexia nervosa), delinkuensi (kenakalan) remaja, dan masalah penyesuaian diri lainnya. Menurut penelitian Donnellan et al. (2005), self-esteem yang rendah berhubungan dengan agresi, perilaku antisosial, dan delinkuensi. Selain itu, selfesteem yang rendah selama masa remaja berhubungan positif dengan kesehatan yang buruk, perilaku kriminal, dan kesulitan ekonomi pada masa dewasa (Trzesniewski et al., 2006) serta memprediksi munculnya depresi di masa dewasa (Orth, Robins, \& Roberts, 2008).

Hasil penelitian Novariandhini dan Latifah (2012) menunjukkan bahwa masih terdapat remaja yang memiliki self-esteem rendah sebanyak 6,9 persen dari 86 remaja pada tiga sekolah menengah di Kota Bogor. Perilaku self-esteem rendah ditunjukkan oleh remaja yang merasa tidak berguna, tidak diperhatikan oleh orang lain, tidak memiliki sesuatu yang dapat dibanggakan, tidak diperhatikan oleh orang-orang di sekelilingnya, dan merasa tanggung jawab tidak pernah diberikan kepada dirinya. Penelitian tersebut menunjukkan bahwa jumlah remaja dengan self-esteem yang rendah tidaklah banyak, namun penelitian Ma'rifah dan Budiani (2012) menunjukkan jumlah remaja yang memiliki self-esteem di bawah rata-rata atau rendah yang cukup banyak, yaitu 53,4 persen dari 58 orang contoh.

Salah satu faktor yang berpengaruh terhadap rasa percaya diri remaja adalah interaksi dengan orang tua. Menurut Ansari dan Qureshi (2013), pengasuhan penerimaan berhubungan dengan self-esteem yang tinggi, sebaliknya pengasuhan penolakan berhubungan dengan self-esteem yang rendah. Interaksi remajaorang tua yang baik terbentuk lewat pengasuhan yang dilakukan oleh orang tua. Selain faktor pengasuhan orang tua, interaksi dengan saudara kandung juga berhubungan dengan self-esteem remaja (Oliva \& Arran, 2005). Sejalan dengan hubungan orang tua yang baik, interaksi dengan saudara kandung juga dapat terbentuk dengan baik (Hurlcok, 1980). Sebaliknya dengan interaksi orang tua dan saudara kandung yang tidak baik akan membentuk self-esteem yang rendah.

Menurut Plomin dan Daniels (2011), anakanak dari keluarga yang sama tidak dilahirkan ke dalam lingkungan yang sama, hal ini disebabkan oleh adanya situasi psikologis yang unik akibat adanya urutan kelahiran. Anak pertama yang awalnya mendapatkan perhatian penuh dari orang tua akan cenderung berusaha untuk menunjukkan dirinya dan menjadi yang pertama atau pemenang, sedangkan anak kedua cenderung akan berusaha untuk mengejar pencapaian kakaknya. Dengan begitu, anak kedua menganggap penting peran seorang anak sulung atau kakaknya dan menjadikannya sebagai standar dalam menilai dirinya. Selain itu, susunan jenis kelamin anak juga akan menentukan interaksi di antara anak. Jenis kelamin yang sama antara saudara kandung membuat saudara akan lebih dekat daripada jenis kelamin yang berbeda (Conger \& Little, 2010).

Berdasarkan latar belakang yang telah dirumuskan tersebut maka penting untuk melakukan penelitian tentang self-esteem, khususnya pada remaja perempuan yang mempunyai kakak dan kaitannya dengan pengasuhan orang tua dan interaksi saudara kandung. Berdasarkan pemaparan tersebut maka penelitian ini bertujuan untuk: (1) menganalisis perbedaan pengasuhan penerimaan-penolakan ibu, interaksi saudara kandung, dan self-esteem pada remaja perempuan anak kedua yang memiliki kakak 
laki-laki dengan yang memiliki kakak perempuan; dan (2) menganalisis hubungan pengasuhan penerimaan-penolakan ibu dan interaksi saudara kandung terhadap selfesteem pada remaja perempuan anak kedua.

\section{METODE}

Penelitian ini menggunakan desain cross sectional study, artinya penelitian dilakukan dalam satu waktu tertentu. Metode yang digunakan untuk mengumpulkan data dalam penelitian ini adalah survei. Lokasi penelitian dilakukan di salah satu SMP Negeri di Kecamatan Dramaga, Kabupaten Bogor; yang dipilih secara purposive untuk mendapatkan remaja yang sesuai dengan kriteria penelitian.

Populasi pada penelitian ini adalah seluruh siswi di sekolah terpilih yang berusia 13-16 tahun dan berstatus anak kandung kedua dalam keluarganya. Contoh dipilih secara purposif dengan kriterianya adalah anak perempuan kedua yang memiliki kakak pertama kandung yang tinggal satu rumah dan diasuh oleh orang tua yang sama serta berasal dari keluarga inti (intact family). Remaja perempuan yang merupakan anak kedua di sekolah terpilih berjumlah 63 orang dengan jumlah contoh yang digunakan hanya 60 orang siswi karena tiga orang siswi lainnya tidak memenuhi kriteria. Siswi yang mempunyai kakak perempuan berjumlah 30 orang dan siswi yang memiliki kakak laki-laki berjumlah 30 orang.

Data yang dikumpulkan dan kemudian dianalisis untuk menjawab tujuan dalam penelitian ini adalah data primer. Data primer yang digunakan dalam penelitian ini meliputi karakteristik remaja (usia dan jenis kelamin), karakteristik kakak remaja (usia dan jenis kelamin), karakteristik keluarga (usia orang tua, lama pendidikan orang tua, besar keluarga), pengasuhan penerimaan-penolakan ibu, interaksi saudara kandung, dan selfesteem remaja.

Data pengasuhan penerimaan-penolakan ibu berdasarkan persepsi remaja diperoleh menggunakan kuesioner Parental AcceptanceRejection Questionnaire (PAR Q) yang diadaptasi dari Rohner (1986) dengan nilai Cronbach's Alpha 0,851. Instrumen PAR Q terdiri atas 60 butir pertanyaan yang mencakup 20 butir pertanyaan untuk penerimaan (acceptance), 15 butir pertanyaan untuk agresivitas (hostility/aggression), 15 butir pertanyaan untuk pengabaian (neglect), dan 10 butir pertanyaan untuk penolakan (rejection). Instrumen tersebut menggunakan 4 skala penilaian ( $1=$ tidak benar; $2=$ jarang, $3=$ kadang-kadang; 4=hampir selalu benar).

Sementara itu, interaksi saudara kandung diukur menggunakan instrumen Sibling Relationship Questionnaire (SRQ) dari Furman dan Buhrmester (1985) yang dimodifikasi oleh peneliti dengan nilai Cronbach's Alpha 0,805. Instrumen tersebut memiliki 48 butir pertanyaan yang terdiri dari 15 butir pertanyaan untuk kehangatan, 21 butir pertanyaan untuk kekuatan relatif, 6 butir pertanyaan untuk persaingan, dan 6 butir pertanyaan untuk dimensi konflik. Penilaian SRQ menggunakan skala 1-4 yaitu $1=$ tidak sama sekali; 2 =jarang; $3=$ sering; $4=$ sangat sering.

Selanjutnya, data self-esteem remaja diperoleh menggunakan instrumen Coopersmith (1989) dalam Howe (2002) yang telah dimodifikasi oleh peneliti dengan nilai Cronbach's Alpha 0,699 . Instrumen tersebut terdiri dari 58 pernyataan dengan 8 pernyataan pengecoh, sehingga 8 pernyataan tersebut tidak dihitung dalam penilaian. Kedelapan pernyataan tersebut, yaitu pernyataan pertama, ke-6, ke13, ke-20, ke-27, ke-34, ke-41, dan ke-48 (Johnson et al., 1983). Instrumen tersebut menggunakan skala penilaian $0-1$, yaitu $0=$ tidak menggambarkan saya dan $1=$ menggambarkan saya .

Data diolah melalui beberapa tahapan, yaitu proses editing, coding, scoring, entry data, cleaning, dan analyzing data. Data diolah menggunakan Microsoft Excel dan Statistical Package for Social Science (SPSS) for Windows. Hasil pengolahan data dianalisis secara deskriptif dan inferensia. Analisis deskriptif dilakukan untuk menjelaskan karakteristik remaja, keluarga, dan karakteristik kakak (usia, lama pendidikan, dan besar keluarga), pengasuhan penerimaan-penolakan ibu, interaksi saudara kandung, dan selfesteem remaja.

Pengasuhan penerimaan-penolakan ibu dan interaksi saudara kandung dibedakan ke dalam kategori rendah (<rata-rata) dan tinggi ( $\geq$ rata-rata). Menurut Rafati et al. (2014), pengkategorian self-esteem didasarkan pada cut-off rendah (<rata-rata) dan tinggi ( $\geq$ ratarata). Skor yang diperoleh untuk variabel pengasuhan penerimaan-penolakan, interaksi saudara kandung, dan self-esteem remaja selanjutnya dibuat indeks dengan penghitungan sebagai berikut: 


\author{
$Y=\frac{(X-n i l a i ~ m i n i m u m)}{(\text { Nilai maksimum-nilai minimum) }} \times 100$ \\ Keterangan: \\ $Y=$ Skor dalam persen \\ $\mathrm{X}=$ Skor yang diperoleh untuk setiap contoh
}

Selain itu, dilakukan uji beda (independent simple $t$-test) untuk menganalisis perbedaan antara pengasuhan penerimaan-penolakan ibu, interaksi saudara kandung, dan selfesteem pada remaja yang memiliki kakak perempuan dan kakak laki-laki. Uji hubungan dilakukan untuk menganalisis hubungan antara karakteristik remaja, karakteristik kakak, karakteristik keluarga, pengasuhan penerimaan-penolakan ibu, interaksi saudara kandung, dengan self-esteem remaja.

\section{HASIL}

\section{Karakteristik Remaja, Kakak, dan Keluarga}

Hasil penelitian menunjukkan bahwa rata-rata usia remaja dengan kakak perempuan dan remaja dengan kakak laki-laki adalah 13,93 tahun dan 14,10 tahun. Proporsi terbanyak remaja dengan kakak perempuan berusia 13 tahun $(43,3 \%)$ dan proporsi terbanyak remaja dengan kakak laki-laki berusia 14 tahun $(46,7 \%)$. Rata-rata usia kakak perempuan dan kakak laki-laki sebesar 18,70 tahun dan 19,13 tahun. Hasil penelitian juga menemukan bahwa separuh dari kakak perempuan dalam penelitian ini $(56,7 \%)$ berada pada kategori remaja (13-18 tahun), sedangkan kakak lakilaki remaja $(53,30)$ berada pada kategori dewasa awal (18-14 tahun). Selain itu, sebanyak 70,0 persen remaja dengan kakak perempuan dan 76,7 persen remaja dengan kakak laki-laki memiliki jarak usia lebih dari sama dengan 4 tahun dengan kakaknya.

Hasil juga menunjukkan rata-rata usia ibu remaja dengan kakak perempuan dan remaja dengan kakak laki-laki sebesar 40,83 tahun dan 42,20 tahun. Selain itu, separuh ibu remaja dengan kakak perempuan $(53,3 \%)$ termasuk kategori dewasa awal (20-40 tahun) dan separuh ibu remaja dengan kakak laki-laki $(56,7 \%)$ termasuk kategori dewasa madya (4060 tahun). Rata-rata lama pendidikan ibu remaja dengan kakak perempuan dalam penelitian dan ibu remaja dengan kakak lakilaki, yaitu 9,27 tahun dan 8,83 tahun. Hasil penelitian juga menunjukkan bahawa sebanyak 40,0 persen ibu remaja dalam penelitian ini hanya menyelesaikan pendidikan selama 6 tahun atau setara Sekolah Dasar (SD). Sementara itu, sebanyak 33,3 persen keluarga remaja dengan kakak perempuan berada pada kategori keluarga besar ( $>7$ orang), sedangkan 63,3 persen remaja dengan kakak laki-laki berada pada kategori keluarga sedang (5-7 orang).

\section{Pengasuhan Penerimaan-Penolakan Ibu}

Hasil penelitian menunjukkan tidak terdapat perbedaan signifikan dari pengasuhan penerimaan-penolakan ibu pada remaja berdasarkan jenis kelamin kakak. Hal ini terlihat dari rata-rata capaian pengasuhan penerimaan-penolakan ibu yang tidak jauh berbeda antara remaja dengan kakak perempuan dan remaja dengan kakak laki-laki. Rata-rata dimensi penerimaan dari PAR ditemukan paling tinggi dibandingkan dengan dimensi PAR lainnya. Sementara itu, dimensi pengabaian PAR pada remaja dengan kakak perempuan paling rendah dibandingkan dengan dimensi lainnya. Temuan lain yaitu dimensi agresivitas pada remaja dengan kakak laki-laki paling rendah dibandingkan dengan dimensi lainnya bila dianalisis berdasarkan jenis kelamin kakak remaja (Tabel 1).

Analisis proporsi remaja berdasarkan skor pengasuhan penerimaan-penolakan menunjukkan bahwa separuh dari remaja dengan kakak perempuan $(50,0 \%)$ dan lebih dari separuh remaja dengan kakak laki-laki $(56,7 \%)$ merasa bahwa ibunya telah memberikan dimensi penerimaan yang tinggi; sedangkan sisanya menilai ibunya memberikan penerimaan yang rendah. Hasil penelitian juga menunjukkan bahwa sekitar tujuh dari sepuluh remaja dengan kakak perempuan $(66,7 \%)$ dan remaja dengan kakak laki-laki $(63,3 \%)$ terkategori sebagai remaja yang mempersepsikan agresivitas ibu dalam pengasuhannya rendah. Remaja yang memiliki kakak perempuan maupun laki-laki terkategori memiliki ibu yang pengabaiannya tinggi (di atas rata-rata). Hasil yang berbeda ditemukan pada pengasuhan penolakan. Remaja dengan kakak perempuan sebanyak 53,3 persen menilai ibunya memiliki dimensi penolakan yang tinggi. Sementara itu, 63,3 persen remaja dengan kakak laki-laki menilai dimensi pengasuhan penolakan ibu terkategori rendah.

Berdasarkan hasil analisis, pengasuhan penerimaan-penolakan ibu pada remaja dengan kategori tinggi dicirikan dengan remaja merasa bahwa ibu menunjukkan kehangatan dan perhatian kepada remaja. Hal ini terlihat dari sebanyak 75,0 persen remaja yang memiliki persepsi bahwa ibu hampir selalu mengatakan betapa bangganya ibu ketika remaja melakukan hal baik. 
Tabel 1 Rata-rata indeks capaian skor pengasuhan penerimaan-penolakan berdasarkan jenis kelamin kakak

\begin{tabular}{lccc}
\hline \multirow{2}{*}{$\begin{array}{c}\text { Dimensi } \\
\text { Pengasuhan }\end{array}$} & \multicolumn{2}{c}{ Jenis kelamin kakak } & p- \\
\cline { 2 - 3 } & Perempuan & Laki-laki & value \\
\hline Penerimaan & $70,16 \pm 12,75$ & $74,33 \pm 11,93$ & 0,197 \\
Agresivitas & $18,29 \pm 14,11$ & $18,14 \pm 13,16$ & 0,967 \\
Pengabaian & $17,25 \pm 9,34$ & $18,22 \pm 10,28$ & 0,706 \\
Penolakan & $21,88 \pm 11,92$ & $21,44 \pm 10,88$ & 0,881 \\
\hline
\end{tabular}

Hasil penelitian menemukan bahwa sebanyak 65,0 persen remaja menyatakan bahwa ibu hampir selalu membuat remaja merasa lebih nyaman saat remaja luka atau sakit. Selain itu, sebanyak 70,0 persen ibu memperlakukan remaja dengan lembut dan kasing sayang. Temuan penelitian ini juga menunjukkan adanya remaja yang menyatakan bahwa ibu hampir selalu berusaha untuk membuat remaja bahagia $(81,7 \%)$.

Sebaliknya, pengasuhan penerimaan kategori rendah muncul karena masih terdapat remaja yang merasa ibu tidak pernah menyuruh membawa teman ke rumah dan memberikan suasana yang menyenangkan untuk remaja dan temannya $(15,0 \%)$. Temuan menunjukkan bahwa terdapat remaja yang merasa bahwa ibu tidak pernah memuji remaja di depan orang lain (20,0\%). Selain itu, sekitar 4 dari 10 remaja menyatakan bahwa ibunya tidak pernah mengizinkan untuk melakukan hal yang menurut remaja penting, namun menurut ibunya tidak penting $(43,3 \%)$.

Ditemukan pada sebagian besar remaja memiliki persepsi pengasuhan ibu dengan agresivitas rendah karena remaja merasa tidak pernah diperolok dan dipermainkan oleh ibunya $(81,7 \%)$. Remaja juga tidak merasa bahwa ibu memperlakukannya dengan kasar $(86,7 \%)$, menghukum remaja dengan berat ketika marah $(86,7 \%)$, dan seenaknya menyakiti perasaan remaja (86,7\%). Remaja juga menyatakan bahwa ibu tidak pernah memukul remaja, meskipun remaja tidak melakukan kesalahan (88,3\%). Temuan lainnya adalah sebanyak 86,7 persen remaja menyatakan bahwa ibu tidak pernah mempermalukan remaja di depan temannya.

Penelitian ini juga menemukan bahwa setengah remaja memiliki persepsi pengasuhan ibu pada dimensi pengabaian pada kategori rendah karena remaja merasa bahwa ibu memberikan perhatian secara penuh pada remaja $(55,0 \%)$, ibu menikmati kebersamaan bersama remaja $(61,7 \%)$, ibu memastikan bahwa remaja memperoleh makanan yang sehat $(56,7 \%)$, dan ibu memberikan perhatian besar kepada remaja $(55,0 \%)$. Selain itu, remaja menyatakan bahwa ibu tidak menolak kehadiran remaja $(96,7 \%)$ dan ibu tidak melupakan hal yang seharusnya ibu lakukan untuk remaja $(71,7 \%)$. Remaja juga menyatakan bahwa ibu tidak berusaha menjauhkan diri dari remaja $(95,0 \%)$. Selain itu, hampir seluruh remaja $(93,3 \%)$ menyatakan bahwa ibu tidak meminta orang lain (tetangga atau saudara) untuk mengasuh remaja.

Selain itu, remaja yang memiliki persepsi pengasuhan ibu pada dimensi penolakan pada kategori rendah. Hasil tersebut dapat dijelaskan karena mereka merasa bahwa ibu tidak menunjukkan penolakan terhadap diri remaja. Hal ini terlihat dari 70,0 persen remaja menyatakan bahwa ibu tidak membuat remaja merasa malu dan salah saat remaja melakukan hal yang tidak benar. Selain itu, sebanyak 91,7 persen remaja tidak merasa bahwa ibu tidak mencintai remaja dan ibu tidak terlihat menyukai remaja. Remaja juga menyatakan bahwa ibu tidak membuat perasaan tak lagi dicintai saat remaja berbuat salah $(68,3 \%)$ dan ibu tidak mengeluh tentang diri remaja $(63,3 \%)$. Temuan penelitian juga menunjukkan bahwa sebanyak 98,3 persen remaja tidak merasa bahwa ibu memperlihatkan kepada remaja jika remaja tidak diinginkan.

\section{Interaksi Saudara Kandung}

Hasil penelitian menemukan bahwa terdapat perbedaan signifikan dari interaksi saudara kandung pada dimensi kehangatan pada remaja dengan kakak laki-laki dan kakak perempuan $(p=0,001)$. Interaksi saudara kandung pada dimensi kehangatan remaja perempuan yang menjadi responden dalam penelitian ini dengan kakak perempuan lebih tinggi dibandingkan remaja dengan kakak lakilaki. Hal ini terlihat dari selisih rata-rata indeks capaian interaksi saudara kandung pada dimensi kehangatan remaja dengan kakak perempuan dan remaja dengan kakak laki-laki sebesar 13,64 dengan rata-rata remaja dengan kakak perempuan lebih tinggi. Namun, interaksi saudara kandung pada dimensi kekuatan relatif, konflik, dan persaingan tidak memiliki perbedaan yang signifikan pada remaja dengan kakak laki-laki dan kakak perempuan. Hasil menunjukkan interaksi saudara kandung pada dimensi kehangatan paling tinggi dibandingkan dengan dimensi lainnya. Interaksi saudara kandung dimensi konflik paling rendah dibandingkan dengan interkasi saudara kandung dimensi lainnya (Tabel 2). 
Tabel 2 Rata-rata indeks capaian skor interaksi saudara kandung berdasarkan jenis kelamin kakak

\begin{tabular}{llcc}
\hline $\begin{array}{c}\text { Interaksi saudara } \\
\text { kandung }\end{array}$ & Perempuan & Laki-laki & p-value \\
\hline Kehangatan & $64,66 \pm 14,11$ & $51,02 \pm 15,08$ & $0,001^{*}$ \\
Kekuatan relatif & $55,00 \pm 11,35$ & $49,62 \pm 15,47$ & 0,131 \\
Konflik & $34,44 \pm 16,40$ & $29,72 \pm 11,16$ & 0,198 \\
Persaingan & $55,00 \pm 12,14$ & $56,48 \pm 15,37$ & 0,680 \\
\hline
\end{tabular}

Analisis berdasarkan proporsi remaja, hasil penelitian menunjukkan bahwa satu dari dua remaja dengan kakak perempuan $(50,0 \%)$ memiliki interaksi saudara kandung kehangatan kategori tinggi dan sekitar dua dari tiga remaja dengan kakak laki-laki $(66,7 \%)$ memiliki interaksi saudara kandung kehangatan kategori rendah. Selain itu, hampir separuh remaja dengan kakak perempuan $(46,7 \%)$ dan separuh remaja dengan kakak laki-laki (50,0\%) memiliki interaksi saudara kandung pada dimensi kekuatan relatif yang tinggi. Selain itu, separuh remaja dengan kakak perempuan $(53,3 \%)$ dan remaja dengan kakak laki-laki $(50,0 \%)$ memiliki konflik yang tinggi dengan kakaknya. Temuan penelitian juga menunjukkan bahwa terdapat separuh remaja dengan kakak perempuan $(50,0 \%)$ dan hampir separuh remaja dengan kakak laki-laki $(46,7 \%)$ memiliki interaksi saudara kandung dimensi persaingan kategori tinggi.

Remaja perempuan dalam penelitian ini merasa memiliki interaksi saudara kandung pada dimensi kehangatan yang rendah dengan kakak laki-lakinya karena adanya remaja yang merasa tidak pernah memiliki kesukaan yang sama dengan kakaknya (40,0\%), tidak pernah bercerita kepada kakaknya $(30,0 \%)$, tidak pernah merasa saling menyayangi dengan kakaknya (20,0\%), dan tidak pernah memiliki kesamaan dengan kakaknya (40,0\%). Sementara itu, sekitar separuh remaja dengan kakak laki-laki menyatakan tidak pernah berbagi rahasia dengan kakaknya (53,3\%). Remaja dengan kakak laki-laki juga ada yang merasa tidak pernah menceritakan hal yang tidak ingin diketahui oleh orang lain $(46,7 \%)$ dan tidak pernah merasa memiliki kemiripan dengan kakaknya (30,0\%).

Meskipun begitu, interaksi saudara kandung pada dimensi kekuatan relatif kategori tinggi muncul karena sebanyak 23,3 persen remaja perempuan pada penelitian ini merasa bahwa kakaknya menunjukkan bagaimana cara untuk melakukan sesuatu yang remaja tidak tahu. Selain itu, sebanyak seperempat remaja merasa bahwa kakaknya memberi tahu remaja apa yang harus remaja lakukan $(25,0 \%)$ dan meminta remaja untuk melakukan sesuatu $(25,0 \%)$. Selain itu, juga ditemukan bahwa terdapat 20,0 persen remaja yang memiliki persepsi bahwa kakak selalu mengajari remaja yang tidak remaja ketahui dan kakak hampir selalu memerintah remaja. Interaksi saudara kandung dimensi konflik kategori tinggi muncul karena kadang-kadang remaja dan kakaknya tidak sependapat satu sama lain $(21,7 \%)$ dan juga bertengkar dengan kakaknya $(46,7 \%)$. Temuan lainnya menemukan bahwa sebanyak 21,7 persen remaja merasa kadang-kadang berbeda pendapat dengan kakaknya dan 33,3 persen merasa kadang-kadang berusaha untuk tampil lebih baik di hadapan orang tuanya.

Sementara itu, interaksi saudara kandung pada dimensi persaingan kategori tinggi muncul karena sebanyak 21,7 persen remaja merasa bahwa ayahnya memperlakukan dan memberikan perhatian lebih kepada kakak remaja. Selain itu, 20,0 persen remaja memiliki persepsi bahwa ayahnya lebih mengutamakan kakaknya daripada dirinya.

\section{Self-Esteem Remaja}

Penghargaan diri (self-esteem) adalah keseluruhan cara individu dalam mengevaluasi dirinya mengacu pada persepsi mengenai nilai seseorang sebagai manusia, keberhasilan, dan pencapaian seseorang, misalnya remaja merasa pintar dan menarik (Santrock, 2011). Hasil penelitian ini menunjukkan bahwa tidak terdapat perbedaan self-esteem remaja perempuan berdasarkan jenis kelamin kakak, dengan selisih rata-rata sebesar 0,66. Ratarata self-esteem remaja perempuan dengan kakak perempuan mencapai 66,06 , rata-rata self-esteem remaja perempuan dengan kakak laki-laki mencapai 65,40 , dan rata-rata selfesteem remaja perempuan secara keseluruhan mencapai 65,73. Proporsi terbanyak remaja dalam penelitian ini memiliki self-esteem yang tinggi, yaitu 56,7 persen. Separuh remaja dengan kakak perempuan $(53,3 \%)$ dan lebih dari separuh remaja dengan kakak laki-laki (60,0\%) memiliki self-esteem yang tinggi.

Remaja memiliki self-esteem rendah disebabkan oleh adanya separuh remaja yang menyatakan bahwa remaja sering berharap menjadi orang lain $(55,0 \%)$, seseorang harus selalu memberitahu remaja apa yang harus dilakukan $(51,7 \%)$, sering merasa kesal di sekolah $(51,7 \%)$, sering merasa malu $(51,7 \%)$, dan mudah marah saat dimarahi $(58,3 \%)$. Remaja juga sering merasa rendah diri di 
sekolah $(43,3 \%)$, remaja mudah merasa marah di rumah $(45,0 \%)$, merasa lama membiasakan diri pada hal yang baru (45,0\%). Hasil penelitian juga menemukan bahwa terdapat sebanyak 81,7 persen remaja yang merasa orang tua berharap banyak terhadap dirinya dan sebanyak 71,7 persen remaja merasa tidak secantik atau setampan orang lain.

\section{Hubungan Karakteristik Remaja, Karakteristik Keluarga, Pengasuhan Penerimaan-Penolakan Ibu, Interaksi Saudara Kandung, dan Self-Esteem}

Hasil penelitian ini menunjukkan bahwa terdapat hubungan signifikan positif antara usia remaja dengan skor PAR secara total. Hal ini menunjukkan bahwa semakin tinggi usia remaja perempuan yang lahir sebagai anak kedua maka semakin tinggi skor pengasuhan penerimaan-penolakan ibu. Sementara itu, lama pendidikan ibu juga berhubungan signifikan positif dengan skor PAR secara total. Hasil ini menegaskan bahwa semakin tinggi lama pendidikan ibu maka semakin tinggi pengasuhan penerimaan-penolakan ibu (Tabel 3). Selanjutnya penelitian ini tidak menemukan adanya hubungan yang signifikan antara karakteristik remaja, kakak, dan keluarga dengan interaksi saudara kandung. Hal ini ditunjukkan dari ketiadaan hubungan signifikan antara usia remaja, usia kakak, usia ibu, lama pendidikan ibu, dan besar keluarga dengan interaksi saudara kandung.

Pengasuhan dimensi agresivitas ibu berhubungan signifikan positif dengan interaksi saudara kandung dimensi konflik. Hal ini menunjukkan bahwa semakin tinggi agresivitas ibu maka semakin tinggi konflik yang terjadi antara remaja perempuan dengan kakaknya. Selain itu, terdapat hubungan signifikan negatif agresivitas ibu dengan interaksi saudara kandung dimensi persaingan. Hasil ini mengindikasikan bahwa semakin tinggi agresif ibu dalam mengasuh anaknya maka semakin rendah persaingan yang terjadi antara remaja perempuan dengan kakaknya. Penelitian ini juga menemukan bahwa terdapat hubungan signifikan negatif antara pengasuhan ibu dimensi pengabaian dengan interaksi saudara kandung dimensi persaingan. Hasil ini juga menunjukkan bahwa semakin tinggi pengabaian terhadap anaknya maka persaingan remaja perempuan dengan kakaknya semakin rendah (Tabel 4).

Pengasuhan ibu pada dimensi penolakan memiliki hubungan signifikan positif dengan interaksi saudara kandung dimensi kekuatan relatif. Artinya bahwa semakin tinggi penolakan ibu dalam praktek pengasuhan yang dirasakan remaja perempuan maka semakin tinggi interaksi saudara kandung pada dimensi kekuatan relatif. Pengasuhan dimensi penolakan juga memiliki hubungan signifikan positif dengan interaksi saudara kandung dimensi konflik. Hasil tersebut menunjukkan bahwa semakin tinggi pengasuhan ibu pada dimensi penolakan maka semakin tinggi pula interaksi saudara kandung pada dimensi konflik. Selain itu, pengasuhan penolakan ibu memiliki hubungan signifikan negatif dengan interaksi saudara kandung dimensi persaingan. Hal ini berarti semakin tinggi pengasuhan penolakan maka semakin rendah interaksi saudara kandung dimensi persaingan (Tabel 4).

Hasil penelitian ini juga menunjukkan terdapat hubungan signifikan antara pengasuhan penerimaan-penolakan yang diterapkan ibu dengan self-esteem remaja perempuan yang lahir sebagai anak kedua. Hubungan signifikan positif ditunjukkan antara pengasuhan ibu dimensi penerimaan dengan self-esteem remaja. Temuan ini mengindikasikan bahwa berarti semakin tinggi pengasuhan penerimaan ibu yang dirasakan remaja maka akan semain tinggi self-esteem remaja. Selain itu, terdapat hubungan signifikan negatif antara pengasuhan ibu pada dimensi agresivitas dengan self-esteem remaja. Hasil ini menunjukkan bahwa semakin tinggi pengasuhan agresivitas ibu yang dirasakan anak maka semakin rendah self-esteem remaja perempuan yang lahir sebagai anak kedua.

Tabel 3 Koefisien korelasi antara karakteristik remaja dan keluarga dan pengasuhan penerimaanpenolakan ibu

\begin{tabular}{lcrrr} 
& \multicolumn{4}{c}{ Pengasuhan } \\
& Penerimaan & Agresivitas & Pengabaian & Penolakan \\
\hline Usia remaja & $0,308^{*}$ & 0,135 & $-0,063$ & 0,162 \\
Usia ibu & $-0,740$ & $-0,006$ & $-0,092$ & $-0,048$ \\
Lama pendidikan ibu & $0,268^{*}$ & 0,012 & $-0,040$ & 0,900 \\
Besar keluarga & 0,134 & $-0,106$ & 0,002 & $-0,123$ \\
\hline Keterangan: ${ }^{*}$ nyata pada $p<0,05 ;{ }^{* *}$ nyata pada $p<0,01$ & & &
\end{tabular}


Tabel 4 Hubungan antara pengasuhan penerimaan-penolakan ibu dengan interaksi saudara kandung

\begin{tabular}{lrrrr}
\hline \multirow{2}{*}{ Pengasuhan } & \multicolumn{4}{c}{ Interaksi Saudara Kandung } \\
& Kehangatan & Kekuatan Relatif & Konflik & Persaingan \\
\hline Penerimaan & 0,157 & 0,153 & $-0,251$ & 0,009 \\
Agresifitas & $-0,131$ & 0,229 & $0,385^{* *}$ & $-0,293^{*}$ \\
Pengabaian & $-0,224$ & 0,019 & 0,228 & $-0,320^{*}$ \\
Penolakan & $-0,215$ & $0,301^{*}$ & $0,486^{* *}$ & $-0,320^{*}$ \\
\hline
\end{tabular}

Keterangan: *nyata pada $p<0,05 ;{ }^{* *}$ nyata pada $p<0,01$

Uji korelasi juga menemukan terdapat hubungan signifikan negatif antara pengasuhan dimensi pengabaian dengan selfesteem remaja. Makna hubungan tersebut adalah semakin tinggi pengasuhan pengabaian maka semakin rendah self-esteem remaja perempuan. Hasil lain juga menemukan adanya hubungan signifikan negatif antara pengasuhan dimensi penolakan dengan self-esteem. Hal ini menunjukkan bahwa semakin tinggi pengasuhan penolakan ibu yang dirasakan anak maka semakin rendah self-esteem remaja (Tabel 5).

\section{PEMBAHASAN}

Hasil penelitian menunjukkan bahwa terdapat perbedaan interaksi saudara kandung pada dimensi kehangatan antara remaja perempuan yang terlahir sebagai anak kedua dengan kakak perempuan dan remaja dengan kakak laki-laki. Remaja perempuan dengan kakak perempuan menilai lebih mempunyai interaksi yang hangat dibandingkan remaja perempuan dengan kakak laki-laki. Hasil ini sesuai dengan penelitian Soysal (2016) yang menyatakan bahwa remaja perempuan yang memiliki saudara kandung dengan jenis kelamin yang sama akan cenderung mengalami peningkatan hubungan yang positif dibandingkan dengan remaja perempuan dengan saudara jenis kelaminnya berbeda. Menurut Furman dan Buhrmester (1985) kakak perempuan lebih bersedia menjalin hubungan yang lebih erat dengan saudaranya daripada kakak laki-laki.

Selain itu, hasil penelitian menunjukkan bahwa usia remaja berhubungan positif dengan pengasuhan penerimaan. Hal tersebut tidak sesuai dengan penelitian Asilah dan Hastuti (2014) serta Voluntir dan Alfiasari (2014) bahwa usia remaja berhubungan negatif dengan pengasuhan penerimaan-penolakan. Hasil lain juga menunjukkan bahwa lama pendidikan ibu juga berhubungan positif dengan pengasuhan penerimaan-penolakan ibu. Hal ini sesuai dengan hasil penelitian Asilah dan Hastuti (2014) serta Voluntir dan Alfiasari (2014) bahwa lama pendidikan ibu berhubungan positif dengan pengasuhan penerimaan-penolakan. Hal ini menegaskan bahwa semakin tinggi pendidikan ibu, ibu semakin memiliki pengetahuan mengenai pengasuhan yang baik. Hal ini akan menyebabkan ibu menerapkan pengasuhan penerimaan yang lebih baik.

Selain itu, hasil lain dalam penelitian ini menunjukkan hubungan positif antara pengasuhan penerimaan ibu dengan selfesteem remaja. Persepsi remaja akan pengasuhan ibu yang dipenuhi kasih sayang dan kehangatan berhubungan dengan selfesteem remaja. Hal ini sesuai dengan hasil penelitian Jun, Baharudin, dan Jo-Pei (2013) bahwa semakin tinggi pengasuhan penerimaan maka semakin tinggi juga selfesteem remaja. Selain itu, terdapat hubungan signifikan negatif antara pengasuhan penolakan (hostility, neglect, dan rejection) ibu dengan self-esteem remaja. Hasil tersebut sesuai dengan penelitian Yousaf (2015) yang menunjukkan adanya hubungan antara pengasuhan penolakan dengan self-esteem yang rendah. Menurut penelitian $\mathrm{Naz}$ dan Kausar (2013), pengasuhan penolakan yang meliputi hostility, neglect, dan rejection dapat meningkatkan self-esteem negatif remaja.

Tabel 5 Koefisien korelasi antara karakteristik, pengasuhan penerimaan-penolakan ibu, interaksi saudara kandung, dengan self-esteem

\begin{tabular}{lc}
\hline Variabel & Self-esteem \\
\hline Usia remaja & $-0,009$ \\
Usia kakak & 0,021 \\
Usia ibu & 0,052 \\
Lama pendidikan ibu & 0,088 \\
Besar keluarga & 0,066 \\
Pengasuhan penerimaan & $0,326^{*}$ \\
Pengasuhan agresivitas & $-0,414^{\star *}$ \\
Pengasuhan pengabaian & $-0,496^{\star *}$ \\
Pengasuhan penolakan & $-0,461^{\star *}$ \\
Interaksi saudara kandung & 0,095 \\
kehangatan & \\
Interaksi saudara kandung & 0,020 \\
kekuatan relatif & \\
Interaksi saudara kandung & $-0,238$ \\
konflik & \\
Interaksi saudara kandung & 0,163 \\
persaingan & \\
\hline Keterangan: ${ }^{*}$ nyata pada $p<0,05 ;{ }^{* *}$ nyata pada $p<0,01$
\end{tabular}


Penelitian Yasmin dan Hossain (2014) menunjukkan bahwa pengasuhan penerimaanpenolakan berpengaruh signifikan terhadap self-esteem. Berdasarkan teori interaksi simbolik, individu akan memandang dirinya sendiri sebagaimana orang tua atau orang lain yang merupakan significant other bagi individu. Ketika remaja merasa tidak dicintai oleh ibunya, ia akan merasa tidak pantas dicintai oleh orang lain dan merasa tidak berharga. Dengan adanya penolakan dari ibu, individu akan merasa dirinya bukanlah orang yang baik, individu juga akan cenderung merasa tidak dapat memenuhi kebutuhannya, dan merasa dirinya kurang baik secara menyeluruh (Rohner, Khaleque, \& Cournoyer, 2005).

Pengasuhan penolakan ibu yang dirasakan remaja berhubungan positif dengan interaksi saudara kandung pada dimensi kekuatan relatif. Pengasuhan penolakan merupakan perasaan tidak dicintai, tidak diinginkan, atau ditolak tanpa adanya indikator yang menunjukkan hubungan positif antara anak dan orang tua (Rohner, 1986). Kekuatan relatif atau relative power menunjukkan adanya status atau kekuatan yang diasosiasikan oleh satu saudara mengasumsikan dirinya lebih dominan, bahkan selalu mengambil keuntungan dengan saudaranya (Furman \& Buhrmester, 1985). Dengan penolakan ibu, remaja mencari perhatian lain dari kakaknya yaitu dengan mengambil keuntungan dari kakaknya. Keuntungan tersebut dalam bentuk kakak memberi tahu hal yang harus remaja lakukan dan membantu remaja dalam hal yang tidak dapat dilakukan sendiri.

Sementara itu, pengasuhan agresivitas membuat orang tua bersikap cenderung menyakiti seperti memukul, menendang, melontarkan makian atau berkata kejam kepada anaknya. Hal ini membuat munculnya rasa permusuhan anak terhadap orang tua (Rohner, 1986). Konflik saudara kandung ditunjukkan dengan rendahnya keterlibatan antara saudara kandung, rendahnya komunikasi, kurangnya atau tidak hangatnya hubungan antara saudara kandung, kurang berkembangnya empati, dan tingginya koersi dan agresi (Furman \& Buhrmester, 1985). Dalam penelitian ini, pengasuhan agresivitas berhubungan positif dengan interaksi saudara kandung dimensi konflik. Hal ini sejalan dengan penelitian yang menyatakan bahwa penolakan ibu berhubungan positif dengan konflik saudara kandung (Kanyas, 2008). Selain itu, penelitian ini membuktikan adanya hubungan signifikan positif antara pengasuhan pengabaian ibu yang dirasakan remaja dengan interaksi saudara kandung dimensi konflik. Pengasuhan pengabaian merupakan kondisi kurangnnya perhatian terhadap anak, bahkan ketiadaan perawatan atau pengasuhan anak (Rohner, 1986). Konflik di antara saudara kandung juga dapat dicirikan dengan masingmasing individu saudara kandung sebisa mungkin saling menghindar, tidak ingin terlibat dengan urusan saudaranya (Sunarti, 2004). Dengan ketiadaan perhatian orang tua terhadap anak, ia juga akan mengabaikan saudaranya dan hal tersebut merupakan salah satu konflik dalam interaksi saudara kandung.

Namun, penelitian ini menemukan bahwa pengasuhan agresivitas berhubungan negatif dengan interaksi saudara kandung dimensi persaingan. Persaingan adalah interaksi saudara kandung yang bersifat negatif yang didorong untuk memperebutkan kasih sayang orang tua (Furman \& Buhrmester, 1985). Apabila orang tua cenderung menyakiti anak, anak akan memiliki rasa permusuhan dengan ibunya sehingga tidak ada motivasi bagi anak untuk bersaing dengan saudara kandungnya untuk mendapatkan kasih sayang orang tuanya.

Selain itu, penelitian ini juga menemukan adanya hubungan signifikan negatif pengasuhan pengabaian ibu dengan interaksi saudara kandung dimensi persaingan. Pengasuhan pengabaian ditunjukkan oleh orang tua yang tidak mengurus kebutuhan fisik, kesehatan, pendidikan, dan kebutuhan anak lainnya. Selain itu, orang tua juga tidak memperhatikan keinginan, harapan, dan ketertarikan anak. Dengan demikian, orang tua bersikap tidak responsif kepada kebutuhan anak, tidak memberikan perhatian dan jarang terlibat dengan kegiatan anak (Rohner, 1986). Dengan ketiadaan perhatian ibu terhadap anak, anak tidak memiliki motivasi untuk mendapatkan perhatian orang tua sehingga persaingan saudara kandung semakin rendah.

Temuan lain dalam penelitian ini adalah adanya hubungan signifikan negatif antara pengasuhan penolakan ibu dengan interaksi saudara kandung dimensi persaingan. Kanyas (2008) menyatakan bahwa kasih sayang ibu sangat berperan dalam terbentuknya persaingan antara saudara kandung. Anak menganggap bahwa orang tua tidak memberikan perhatian atau tidak mencintainya apabila memiliki persepsi pengasuhan penolakan (Rohner, 1986). Dengan merasa tidak dicintai orang tua maka tidak terdapat motivasi remaja untuk mendapatkan perhatian ibu. 
Selain itu, hal ini juga dipengaruhi dengan perlakuan ibu terhadap kakak remaja. Persaingan adalah interaksi saudara kandung yang bersifat negatif yang didorong untuk memperebutkan kasih sayang orang tua (Furman \& Buhrmester, 1985). Dalam penelitian ini persaingan remaja dengan kakaknya cenderung rendah. Hasil menunjukkan bahwa hanya sebanyak 10 persen remaja menyatakan bahwa kakak biasanya diperlakukan lebih baik oleh ibu, hanya 13,3 persen remaja menyatakan bahwa kakak lebih mendapatkan perhatian dari ibu, dan hanya 16,7 persen remaja menyatakan bahwa kakak lebih diutamakan ibu. Dengan adanya permusuhan dan ketiadaan perhatian ibu serta tidak adanya perbedaan perhatian kepada kakak remaja, membuat persaingan antara saudara kandung rendah.

Setiap penelitian memiliki keterbatasan dalam pelaksanaannya yang dapat diperbaiki lebih lanjut pada penelitian selanjutnya. Pada penelitian ini jumlah remaja yang mewakili remaja dengan kakak perempuan dan remaja dengan kakak laki-laki hanya 30 orang. Jumlah remaja tersebut terlalu kecil untuk dapat merepresentasikan interaksi saudara kandung yang terjadi pada remaja. Hal tersebut membuat hasil penelitian ini tidak dapat digunakan untuk mengeneralisasikan interaksi saudara kandung remaja pada umumnya.

\section{SIMPULAN DAN SARAN}

Rata-rata usia remaja dengan kakak perempuan dan remaja dengan kakak laki-laki adalah 13,93 tahun dan 14,10 tahun. Rata-rata jarak usia remaja dengan kakak perempuan dan kakak laki-laki adalah 4,93 tahun dan 5,03 tahun. Remaja memiliki persepsi paling tinggi pada dimensi pengasuhan penerimaan ibu dibandingkan dimensi pengasuhan lainnya. Meskipun begitu, tidak terdapat perbedaan nyata antara remaja dengan kakak perempuan dan remaja dengan kakak laki-laki dalam hal pengasuhan yang diterapkan ibu. Interaksi saudara kandung dimensi kehangatan paling tinggi diantara dimensi lainnya; dan interaksi saudara kandung dimensi kehangatan pada remaja perempuan yang terlahir sebagai anak kedua dengan kakak perempuan lebih tinggi daripada remaja dengan kakak laki-laki. Selain itu, remaja dengan kakak perempuan memiliki self-esteem lebih tinggi dari remaja dengan kakak laki-laki meskipun tidak berbeda nyata.

Usia remaja dan lama pendidikan ibu berhubungan positif dengan pengasuhan penerimaan yang berhubungan positif juga dengan self-esteem. Pada remaja terdapat hubungan positif antara pengasuhan agresivitas, pengabaian, dan penolakan dengan self-esteem. Selain itu, pengasuhan penolakan berhubungan positif dengan interaksi saudara kandung dimensi kekuatan relatif. Pengasuhan agresivitas dan penolakan ibu juga berhubungan positif dengan interaksi saudara kandung dimensi konflik; namun pengasuhan agresivitas, pengabaian, dan penolakan ibu berhubungan negatif dengan interaksi saudara kandung dimensi persaingan.

Menurut mayoritas remaja perempuan yang terlahir sebagai anak kedua, pengasuhan yang diterapkan oleh ibu adalah pengasuhan penerimaan. Remaja yang memperoleh pengasuhan penerimaan yang semakin tinggi dari ibunya cenderung memiliki self-esteem yang lebih tinggi. Selain itu, pengasuhan penolakan (agresivitas, penolakan, dan penolakan) membuat self-esteem remaja semakin rendah. Oleh karena itu, disarankan agar para orang tua selalu menerapkan pengasuhan penerimaan dan menghindari pengasuhan penolakan kepada anak untuk dapat meningkatkan self-esteem anak. Selain itu, perbedaan antara interaksi saudara kandung dimensi kehangatan antara remaja dengan kakak perempuan dengan remaja dengan kakak laki-laki membutuhkan perhatian dari orang tua. Orang tua diharapkan memberi dukungan agar interaksi saudara kandung kehangatan remaja dengan kakak laki-laki yang cenderung rendah dapat meningkat. Selain itu, masih adanya self-esteem yang rendah pada remaja juga perlu diperhatikan oleh sekolah, yaitu remaja menyatakan bahwa merasa sulit berbicara di depan kelas, merasa kesal di sekolah, dan merasa rendah diri di sekolah. Hal ini membuat sekolah perlu memperhatikan lebih lanjut self-esteem siswanya, salah satunya dengan cara guru memberikan motivasi untuk siswa.

\section{DAFTAR PUSTAKA}

Ansari, B., \& Qureshi, S.S. (2013). Parental acceptance and penolakan in relation with self-esteem in adolescents. Interdisciplinary Journal of Contemporary Research In Business, 4(11), 552-557. Diambil dari http://journal-

archieves30.webs.com/552-557.pdf. [diunduh 12 Mei 2016]

Asilah \& Hastuti, D. (2014). Hubungan tingkat stress ibu dan pengasuhan penerimaanpenolakan dengan konsep diri remaja 
pada keluarga bercerai. Jurnal IImu Keluarga dan Konsumen, 7(1), 10-18. Diambil dari http://journal.jpb.ac.id/index.php/jikk/artic le/download/9992/7812. [diunduh 13 Mei 2016]

[BPS] Badan Pusat Statistik. (2013). Proyeksi penduduk Indonesia (Indonesia population projection) 2010-2035. Diambil dari: http://indonesia.unfpa.org/application/ass ets/publications/

Proyeksi_Penduduk_Indonesia_20102035.pdf. [diunduh 9 Jan 2016].

Conger, K. J., \& Little, W. M. (2010). Sibling Relationships during the Transition to Adulthood. Child Dev. Perspect, 4(2), 87-94. doi: 10.1111/j.17508606.2010.00123.x

Donnellan, M., Trzesniewski, K. H., Robins, R. W., Moffitt, T. E., \& Caspi, A. (2005). Low self-esteem is related to aggression, antisocial behavior, and delinquency. Psychological Science, 16(4), 328-335. doi: 10.1111/j.0956-7976.2005.01535.

Furman, W., \& Burmester, D. (1985). Children's Perceptions of the Personal Relationships in their social networks. Developmental Psychology, 21(6),10161024. doi: 0012-1649/85/500.75.

Johnson, B. W., Redfield, D. L., Miller, R. L., \& Simpson, R. E. (1983). The Coopersmith self-esteem inventory: a construct validation study. Educational and Psychological Measurement, 43, 907915. doi: $10.1177 / 001316448304300332$

Jun, L. H., Baharudin, R., \& Jo-Pei, T. (2013). Perceived Parental warmth and depression in early adolescents: path analysis on the role of self-esteem as a mediator. Pertanika Journal Social Science and Humanity, 21(1), 166-178. Diambil dari: http://www.pertanika.upm.edu.my/Pertan ika\%20PAPERS/JSSH\%20Vol.\%2021\% 20(1)\%20Mar.

\%202013/11\%20Page\%20165-178.pdf. [diunduh 2 Maret 2016]

Ma'rifah, N. I. \& Budiani, M. S. (2012). Hubungan antara attachment style dan self-esteem dengan kecemasan sosial pada remaja. Jurnal Psikologi: Teori \& Terapan, 3(1), 17-27. Diambil dari http://ejournal.unesa.ac.id/index.php/jurn al_jptt/article/view/6161/8496. [diunduh 13 Mei 2016].
Novariandhini, D. A., \& Latifah, M. (2012). Harga diri, efikasi diri, motivasi belajar dan prestasi akademik siswa SMA pada berbagai model pembelajaran. Jurnal IImu Keluarga dan Konsumen, 5(2), 138146. Diambil dari http://ikk.fema.ipb.ac.id/v2/images/jikk/v5 n2_5.pdf. [diunduh 13 Mei 2016].

Howe, L. (2002). Self-esteem in girls: does physical education make a difference? (Thesis). University of Lethbridge, Canada, United States. Diambil dari http://hdl.handle.net/10133/1081. [diunduh 30 Januari 2016].

Hurlock, E. B. (1980). Psikologi perkembangan: suatu pendekatan sepanjang rentang kehidupan. Jakarta (ID): Penerbit Erlangga.

Kanyas, R. (2008). The influense of sibling configuration and paretal acceptancerejection on the quality of sibling relationships (Thesis). İstanbul Bilgi Üniversitesi Anasayfa, Istanbul, Turkey.

Naz, F., \& Kausar, R. (2013). Parental rejection, personality maladjustment and depressive symptoms in female adolescents in Pakistan. Journal of Humanities And Social Science, 14(1), 56-65. Diambil dari http://www.iosrjournals.org/iosrjhss/papers/Vol14issue1/J01415665.pdf?id=6731. [Diunduh 2 Maret 2017]

Oliva, A. \& Arranz, E. (2005). Sibling relationships during adolescence. European Journal of Developmental Psychology, 2(3), 253-270. doi: 10.1080/17405620544000002.

Orth, U., Robins, R. W., \& Roberts, B. W. (2008). Low self-esteem prospectively predicts depression in adolescence and young adulthood. Journal of Personality and Social Psychology, 95(3), 695-708. doi: 10.1037/0022-3514.95.3.695.

Plomin, R., \& Daniels, D. (2011). Why are children in the same family so different from one another?. International journal of Epidemiology, 40(3), 563-582. doi: 10.1093/ije/dyq148.

Rafati, F., Rafat, S., Mashayekhi, F., Pilchvarzadeh, M., \& Mashayekh, M. (2014). The comparison of the mental health and self-esteem in the gifted and normal adolescents of high schools in Jiroft City in the year 2012-2013. International Journal of Current 
Research and Academic Review, 2(6). 220-228. Diambil dari https://www.ijcrar.com/vol-2-

6/Foozieh\%20Rafati,\%20et\%20al.pdf. [diunduh 7 April 2016]

Rohner, R. P. (1986). The warmth on: foundation of parental acceptancepenolakan theory. California, US: Sage Publication Inc.

Rohner, R. P., Khaleque, A., \& Cournoyer. (2005). Parental acceptance-rejection theory, methods, cross-cultural evidence, and implications. American Antropological Association Journals, 33(3), 299-334. doi: 10.1525/rth.2005.33.3.299.

Santrock, J. W. (2003). Adolescence: edisi keenam. Jakarta, ID: Erlangga.

2011. Perkembangan masa hidup: edisi ketigabelas, jilid 1. Jakarta, ID: Erlangga.

Soysal, F. S. O. (2016). A study on sibling relationships, life satisfaction and Ioneliness level of adolescents. Journal of Education and Training Studies, 4(4), 58-68. doi: 10.11114/jets.v4i4.1240

Sunarti, E. (2004). Mengasuh dengan hati. Jakarta, ID: PT Elex Komputindo.
Trzesniewski, K. H., Donnellan, M. B., Moffitt ,T. E., Robins, R. W., Poulton, R., \& Caspi A. (2006). Low self-esteem during adolescence predicts poor health, criminal behavior, and limited economic prospects during adulthood. Developmental Psychology, 42(2), 381390. doi: 10.1037/0012-1649.42.2.381.

Voluntir, F., \& Alfiasari. (2014). Penerimaan orang tua menentukan lingkungan pengasuhan keluarga dengan anak remaja di wilayah suburban. Jurnal Pendidikan Karakter, 4(3), 294-306. doi: http://dx.doi.org/10.21831/jpk.v0i3.5634.

Diambil dari http://journal.uny.ac.id/index.php/jpka/arti cle/view/5634. [diunduh 7 April 2016].

Yasmin, S., \& Hossain, A. (2014). Relation of parental rejection with self-esteem and life satisfaction of young adults. Dhaka University Journal of Biological Sciences, 23(1), 69-76. doi: 10.3329/dujbs.v23i1.19828.

Yousaf, S. (2015). The relation between selfesteem, parenting style and social anxiety in girls. Journal of education and Practice, 6(1). 140-142. 